Vegetalika. 2018. 7(4): 1-11

\title{
Pengaruh Aplikasi Silika terhadap Pertumbuhan dan Hasil Tanaman Padi (Oryza sativa L.) pada Kondisi Salin
}

\section{The Effect of Silicate Application on Growth and Yield of Rice (Oryza sativa L.) Under Saline Condition}

\author{
Afiffah Ikhsanti, Budiastuti Kurniasih*), Didik Indradewa \\ Departemen Budidaya Pertanian, Fakultas Pertanian, Universitas Gadjah Mada \\ *) Penulis untuk koresponden Email: tuti_b@ugm.ac.id
}

\begin{abstract}
Salinity is one of the abiotic factors that limit the growth and productivity of plants worldwide. Si uptake by plants is known to reduce salinity stress through improvements in plant growth and yield. This research is aimed to study the effect of adding silica on rice growth and yields under saline condition. This research was conducted at the greenhouse, Faculty of Agriculture, Universitas Gadjah Mada from June to September 2017. The research was arranged in a randomized completely block design with 2 factors and 3 blocks as replications. The first factor was the salinity level due to the addition of $\mathrm{NaCl}(\mathrm{N})$ consisting of three levels: non-saline $(<0.4 \mathrm{dS} / \mathrm{m}), 4$, and $8 \mathrm{dS} / \mathrm{m}$. The second factor was the concentration of $\mathrm{SiO}_{2}(\mathrm{~S})$ consisting of $0,1,2$, and $3 \mathrm{mM}$. The results showed that in the absence of silica, the rice plants were unable to withstand the salinity stress as seen from the decrease in dry milled grain, whereas in adding silica concentration 1-2 mM caused the plant to maintain the yield up to salinity $8 \mathrm{dS} / \mathrm{m}$.
\end{abstract}

Keywords : salinity, silicate, rice, growth and yield

\section{INTISARI}

Salinitas merupakan salah satu faktor abiotik yang membatasi pertumbuhan dan produktivitas tanaman di seluruh dunia. Penyerapan Si oleh tanaman diketahui mampu mengurangi cekaman salinitas melalui perbaikan pada pertumbuhan dan hasil tanaman. Penelitian ini bertujuan untuk mempelajari pengaruh penambahan silika terhadap pertumbuhan dan hasil tanaman padi tercekam salinitas. Penelitian ini dilaksanakan di rumah kaca, Fakultas Pertanian, Universitas Gadjah Mada pada bulan Juni-September 2017. Penelitian disusun dalam Rancangan Acak Kelompok Lengkap (RAKL) dengan 2 faktor dan 3 blok yang dijadikan sebagai ulangan. Faktor pertama yaitu tingkat cekaman salinitas akibat penambahan $\mathrm{NaCl}(\mathrm{N})$ yang terdiri atas tiga level yaitu air non salin $(<0,4$ $\mathrm{dS} / \mathrm{m}), 4$, dan $8 \mathrm{dS} / \mathrm{m}$. Faktor kedua adalah konsentrasi $\mathrm{SiO}_{2}(\mathrm{~S})$ yang terdiri dari 0, 1, 2, dan $3 \mathrm{mM}$. Hasil menunjukkan bahwa pada kondisi tanpa pemberian silika, tanaman padi tidak mampu bertahan terhadap cekaman salinitas dilihat dari penurunan gabah kering 
Afiffah Ikhsanti et. al., / Vegetalika. 2018. 7(4): 1-11

giling yang terjadi, sedangkan pada penambahan silika konsentrasi 1-2 mM menyebabkan tanaman mampu mempertahankan hasil hingga salinitas $8 \mathrm{dS} / \mathrm{m}$.

Kata kunci : salinitas, silika, padi, pertumbuhan dan hasil

\section{PENDAHULUAN}

Padi merupakan komoditas tanaman pangan yang menjadi makanan pokok di Indonesia. Proyeksi BPS (2013) menunjukkan bahwa jumlah penduduk Indonesia akan terus meningkat dari 238,5 juta pada tahun 2010 menjadi 305,6 juta pada tahun 2035. Peningkatan jumlah penduduk mendorong meningkatnya kebutuhan pangan terutama yang berasal dari beras. Diketahui bahwa produksi padi (gabah kering giling) tahun 2015 mengalami kenaikan sebanyak 4,51 juta ton (6,37 persen) dibandingkan tahun 2014 (BPS, 2016). Melihat tren tersebut, peningkatan produktivitas dan atau perluasan areal panenmenjadi suatu hal yang penting dilakukan demi memenuhi kebutuhan salah satunya melalui pemanfaatan lahan marginal daerah pesisir pantai.

Daerah pesisir yang berada didekat garis pantai akan memiliki potensi yang besar untuk terkena cekaman salinitas (Zalensky, 1999). Suwarno (1985) menjelaskan bahwa pengaruh salinitas terhadap tanaman mencakup tiga aspek yaitu mempengaruhi tekanan osmosis, keseimbangan hara, dan pengaruh racun. Modifikasi yang dapat dilakukan pada lingkungan tumbuh tanaman dapat dilakukan dengan berbagai cara salah satunya dengan menambahkan bahan pembenah tanah pada media tumbuh. Si diketahui bermanfaat untuk pertumbuhan tanaman dibawah kondisi cekaman abiotik seperti garam, kekeringan, keracunan logam maupun cekaman biotik seperti cekaman penyakit dan hama (Liang et al., 2003 cit. Ma et al., 2004). Liang et al. (2005) menyatakan bahwa akumulasi unsur silikon dalam bentuk asam silikat $\left(\mathrm{Si}(\mathrm{OH})_{4}\right)$ di dinding sel daun, akar, dan batang memberi keuntungan bagi tanaman yakni membantu mengurangi keracunan ion melalui peningkatan aktivitas enzim antioksidan selama cekaman.

Beberapa mekanisme memungkinkan Si mampu meningkatkan toleransi tanaman terhadap cekaman salinitas (Liang et al., 2003 cit. Ali et al., 2009) meliputi peningkatan status air tanaman (Romero-Aranda et al., 2006), stimulasi spesies oksigen reaktif (ROS) (Zhu et al., 2004 cit. Ali et al., 2009), imobilisasi racun ion $\mathrm{Na}^{+}$(Liang et al., 2003 cit. Ali et al., 2009), mengurangi penyerapan $\mathrm{Na}^{+}$dan penukaran pengambilan $\mathrm{K}^{+}$(Yeo et al., 1999) dan selektivitas tinggi $\mathrm{K}^{+}: \mathrm{Na}^{+}$(Hasegawa et al., 2000 cit. Ali et al., 2009). Melihat besarnya 
Afiffah Ikhsanti et. al., / Vegetalika. 2018. 7(4): 1-11

potensi pengembangan yang dimiliki, maka penelitian ini dilakukan dengan tujuan mempelajari pengaruh penambahan silika terhadap pertumbuhan dan hasil tanaman padi tercekam salinitas.

\section{BAHAN DAN METODE PENELITIAN}

Penelitian ini dilaksanakan di Rumah Kaca, Fakultas Pertanian, Universitas Gadjah Mada pada bulan Juni-September 2017. Objek penelitian ini ialah tanaman padi (Oryza sativa L.) varietas IR64. Penelitian disusun dalam Rancangan Acak Kelompok Lengkap (RAKL) dengan 2 faktor dan 3 blok yang dijadikan sebagai ulangan. Faktor pertama yaitu tingkat cekaman salinitas akibat penambahan $\mathrm{NaCl}(\mathrm{N})$ yang ditunjukan dari daya hantar listrik tanah yang terdiri atas tiga level yaitu non salin $(<0,4 \mathrm{dS} / \mathrm{m}), 4$, dan $8 \mathrm{dS} / \mathrm{m}$. Faktor kedua adalah konsentrasi $\mathrm{SiO}_{2}$ (S) yang terdiri dari 0, 1, 2, dan $3 \mathrm{mM}$. Kombinasi perlakuan yang terbentuk yakni berjumlah 12 kombinasi perlakuan yang terdiri dari 3 perlakuan $\mathrm{NaCl}$ dan 4 perlakuan $\mathrm{SiO}_{2}$. Jumlah unit percobaan adalah 3 blok $\times 12$ kombinasi perlakuan x 5 ulangan = 180 tanaman.

Dalam penelitian ini variabel pengamatan yang diamati antara lain variabel lingkungan, nisbah luas daun, rasio akar/tajuk, jumlah bulir per malai, panjang malai, jumlah malai, indeks panen, bobot 100 bulir, dan gabah kering giling. Data pengamatan yang diperoleh diuji dengan analisis varians pada tingkat signifikansi $5 \%$. Dilanjutkan dengan uji Duncan Multiple Range Test (DMRT) jika hasil analisis varian menunjukkan perbedaan yang nyata antar perlakuan. Analisis data dikerjakan menggunakan perangkat lunak $R$ versi i386 3.1.1. dan SAS 9.1.3.

\section{HASIL DAN PEMBAHASAN}

Salah satu faktor yang mempengaruhi pertumbuhan tanaman adalah keadaan lingkungan iklim mikro tanaman meliputi suhu udara, kelembaban udara relatif, dan cahaya matahari. Pada penelitian ini intensitas cahaya matahari yang diterima tanaman sudah cukup optimal yakni 2.410-20.000 lux. Tercatat suhu siang hari berkisar antara 29$38^{\circ} \mathrm{C}$. Kondisi demikian cukup tinggi bila dibandingkan dengan persyaratan tumbuh tanaman padi yang optimal pada kisaran $22-34^{\circ} \mathrm{C}$ (Krishnan et al., 2011) dan mengakibatkan penurunan hasil tanaman atas suhu $35^{\circ} \mathrm{C}$ (Das et al., 2014). Kelembaban 
Afiffah Ikhsanti et. al., / Vegetalika. 2018. 7(4): 1-11

udara di rumah kaca seringkali bernilai terlalu rendah hingga menyentuh angka 35\%, sehingga kondisi ini kurang sesuai dengan kisaran ideal yang dikehendaki tanaman padi yakni 60-80\% (Rathnayake et al., 2016). Kelembaban udara yang rendah berpotensi meningkatkan transpirasi sehingga serapan air dapat meningkat. Kombinasi faktor lingkungan yang terjadi selama penelitian dapat berpotensi menjadi penyebab hasil tanaman kurang optimal.

Berdasarkan analisis tanah diketahui bahwa tekstur tanah yang digunakan untuk penelitian terdiri atas $71 \%$ pasir, $20 \%$ debu, dan $9 \%$ lempung. Tingginya persentase kandungan pasir menyebabkan sifat tanah yang mudah sekali meloloskan air dan hara. Tanah yang digunakan dalam penelitian ini memiliki tingkat kesuburan yang sangat rendah dilihat dari harkat dan nilai kandungan nitrogen total dan bahan organik tanah berturut-turut $0,07 \%$ dan $0,76 \%$. Berdasarkan panduan umum kesuburan tanah bagi padi, bahan organik yang cukup adalah lebih dari 3\% (Grant, 1965).

Didapatkan hasil bahwa pemberian air kran $(<0,4 \mathrm{dS} / \mathrm{m})$, larutan $\mathrm{NaCl} 4$ dan 8 $\mathrm{dS} / \mathrm{m}$ menghasilkan nilai daya hantar listrik (DHL) tanah berturut-turut sebesar 0,67; 4,8; dan 8,7 dS/m. Pemberian air salin meningkatkan akumulasi garam dalam tanah ditunjukkan dengan DHL tanah yang juga semakin meningkat seiring penyiraman air salin yang dilakukan. Nilai $\mathrm{pH}$ yang terukur pada ketiga perlakuan tingkat salinitas memiliki kisaran yang sama yakni pH 6,0-7,0. Hal ini menunjukkan pemberian salinitas relatif tidak berpengaruh terhadap perubahan nilai $\mathrm{pH}$ dan masih termasuk dalam kategori netral sehingga sesuai dengan syarat tumbuh tanaman padi yakni pada keasaman tanah antara pH 4,0-7,0 (Warintek, 2008). 
Afiffah Ikhsanti et. al., / Vegetalika. 2018. 7(4): 1-11

Tabel 1. Laju nisbah luas daun tanaman padi pada pengaruh tingkat salinitas dan konsentrasi silika yang berbeda

\begin{tabular}{ccc}
\hline \multicolumn{1}{c}{ Perlakuan } & \multicolumn{2}{c}{ Nisbah luas daun $\left(\mathrm{dm}^{2} / \mathrm{g}\right)$} \\
\cline { 2 - 3 } & $3 \mathrm{mspt}$ & $8 \mathrm{mspt}$ \\
\hline Tingkat Salinitas $(\mathrm{NaCl})$ & $3,33 \mathrm{a}$ & $1,04 \mathrm{a}$ \\
$<0,4 \mathrm{dS} / \mathrm{m}$ & $2,40 \mathrm{ab}$ & $0,86 \mathrm{~b}$ \\
$4 \mathrm{dS} / \mathrm{m}$ & $1,76 \mathrm{~b}$ & $0,93 \mathrm{ab}$ \\
$8 \mathrm{dS} / \mathrm{m}$ & & \\
Konsentrasi Silika $\left(\mathrm{SiO}_{2}\right)$ & $2,07 \mathrm{p}$ & $0,91 \mathrm{p}$ \\
$0 \mathrm{mM}$ & $2,54 \mathrm{p}$ & $0,89 \mathrm{p}$ \\
$1 \mathrm{mM}$ & $2,54 \mathrm{p}$ & $0,99 \mathrm{p}$ \\
$2 \mathrm{mM}$ & $3,02 \mathrm{p}$ & $0,99 \mathrm{p}$ \\
$3 \mathrm{mM}$ & $(-)$ & $(-)$ \\
\hline Interaksi & 6,24 & 3,75 \\
\hline Koefisien Keragaman (\%)
\end{tabular}

Keterangan: (-) menunjukkan tidak ada interaksi; angka rerata yang diikuti huruf yang sama pada kolom yang sama menunjukkan tidak adanya beda nyata pada uji Duncan's Multiple Range Test pada taraf $5 \%$. Data ditransformasi menggunakan log $(x)$

Berdasarkan Tabel 1. menunjukkan bahwa tidak terdapat interaksi antara konsentrasi silika dengan tingkat salinitas terhadap nisbah luas daun tanaman padi disetiap fase pertumbuhannya. Perlakuan salinitas menurunkan nisbah luas daun (NLD) baik pada umur 3 dan 8 mspt. Pada umur $3 \mathrm{mspt}$ perlakuan $8 \mathrm{dS} / \mathrm{m}$ secara signifikan menurunkan NLD padi, memasuki umur 8 mspt NLD padi mengalami penurunan pada kondisi $4 \mathrm{dS} / \mathrm{m}$. Nisbah luas daun yang rendah menggambarkan bahwa perlakuan salinitas membuat distribusi fotosintat lebih diarahkan pada pertumbuhan organ selain daun yakni dengan mengakumulasikannya pada akar maupun batang padi sehingga menambah biomassa total yang dihasilkan. Dapat dikatakan keadaan salin menyebabkan terganggunya pembentukan organ penghasil asimilat (source) sehingga menurunkan potensi hasil tanaman padi. Adapun penambahan silika terhadap nisbah luas daun menunjukkan tidak ada pengaruh yang beda nyata baik pada $3 \mathrm{mspt}$ maupun $8 \mathrm{mspt}$. Secara umum tanaman yang diberikan tambahan silika memiliki tren NLD yang lebih tinggi dibandingkan dengan tanaman yang tidak ditambahkan silika. Artinya ada potensi penambahan silika mampu memperbaiki distribusi fotosintat sehingga lebih diarahkan pada pertumbuhan daun dibanding dengan pembentukan organ lainnya. 
Afiffah Ikhsanti et. al., / Vegetalika. 2018. 7(4): 1-11

Tabel 2. Rasio akar dengan tajuk tanaman padi pada pengaruh tingkat salinitas dan konsentrasi silika yang berbeda

\begin{tabular}{cccc}
\hline \multirow{2}{*}{ Perlakuan } & \multicolumn{3}{c}{ Rasio akar/tajuk } \\
\cline { 2 - 4 } & $3 \mathrm{mspt}$ & $8 \mathrm{mspt}$ & $14 \mathrm{mspt}$ \\
\hline Tingkat Salinitas (NaCl) & & & \\
$<0,4 \mathrm{dS} / \mathrm{m}$ & $0,14 \mathrm{a}$ & $0,32 \mathrm{~b}$ & $0,0770 \mathrm{~b}$ \\
$4 \mathrm{dS} / \mathrm{m}$ & $0,13 \mathrm{a}$ & $0,49 \mathrm{a}$ & $0,1143 \mathrm{a}$ \\
$8 \mathrm{dS} / \mathrm{m}$ & $0,16 \mathrm{a}$ & $0,41 \mathrm{ab}$ & $0,1141 \mathrm{a}$ \\
Konsentrasi Silika $\left(\mathrm{SiO}_{2}\right)$ & & & \\
$0 \mathrm{mM}$ & $0,12 \mathrm{p}$ & $0,34 \mathrm{q}$ & $0,085 \mathrm{p}$ \\
$1 \mathrm{mM}$ & $0,14 \mathrm{p}$ & $0,53 \mathrm{p}$ & $0,106 \mathrm{p}$ \\
$2 \mathrm{mM}$ & $0,15 \mathrm{p}$ & $0,37 \mathrm{q}$ & $0,103 \mathrm{p}$ \\
$3 \mathrm{mM}$ & $0,16 \mathrm{p}$ & $0,38 \mathrm{q}$ & $0,112 \mathrm{p}$ \\
\hline Interaksi & $(-)$ & $(-)$ & $(-)$ \\
\hline Koefisien Keragaman (\%) & 49,58 & 36,20 & 27,42 \\
\hline
\end{tabular}

Keterangan: (-) menunjukkan tidak ada interaksi; angka rerata yang diikuti huruf yang sama pada kolom yang sama menunjukkan tidak adanya beda nyata pada uji Duncan's Multiple Range Test pada taraf $5 \%$.

Rasio akar/tajuk menggambarkan besarnya bobot akar tanaman yang dikaitkan dengan tanggapan tanaman terhadap cekaman lingkungan dimana tanaman berfokus pada pertumbuhan akarnya. Berdasarkan Tabel 2. menunjukkan bahwa tidak terdapat interaksi antara konsentrasi silika dan tingkat salinitas terhadap rasio akar/tajuk disemua fase pertumbuhan padi. Pada 8 dan 14 mspt terlihat bahwa perlakuan salinitas mulai dari $4 \mathrm{dS} / \mathrm{m}$ sudah cukup berpengaruh dalam meningkatkan rasio akar/tajuk secara beda nyata bila dibandingkan dengan tanaman non salin. Rasio akar/tajuk yang lebih tinggi pada perlakuan salin menggambarkan bahwa dalam kondisi tercekam salinitas tanaman menanggapi dengan cara memfokuskan pada pertumbuhan akar atau penghambatan pertumbuhan tajuk. Hal ini dilakukan sebagai mekanisme penghindaran tanaman terhadap cekaman salinitas yang diberikan. Pitman (1984) menyatakan bahwa tingginya rasio akar/tajuk dan laju pertumbuhan intrinsik mampu mengurangi laju penyerapan garam pada aliran transpirasi dan akumulasinya di tajuk. Pada $8 \mathrm{mspt}$ terlihat bahwa penambahan konsentrasi $\mathrm{SiO}_{2} 1 \mathrm{mM}$ sudah cukup berpengaruh dalam meningkatkan rasio akar/tajuk secara beda nyata bila dibandingkan dengan tanaman non-salin, namun pada konsentrasi lebih dari itu terlihat terjadi penurunan pada rasio akar/tajuk yang terbentuk. 
Afiffah Ikhsanti et. al., / Vegetalika. 2018. 7(4): 1-11

Tabel 3. Komponen hasil tanaman padi pada pengaruh tingkat salinitas dan konsentrasi silika yang berbeda

\begin{tabular}{|c|c|c|c|c|c|c|}
\hline \multirow[b]{2}{*}{ Perlakuan } & \multirow[b]{2}{*}{$\begin{array}{c}\text { Jumlah } \\
\text { malai per } \\
\text { rumpun }\end{array}$} & \multicolumn{5}{|c|}{ Komponen hasil } \\
\hline & & $\begin{array}{c}\text { Panjang } \\
\text { malai } \\
(\mathrm{cm})\end{array}$ & $\begin{array}{l}\text { Jumlah } \\
\text { bulir total } \\
\text { per malai }\end{array}$ & $\begin{array}{l}\text { Jumlah } \\
\text { bulir isi } \\
\text { per } \\
\text { malai }\end{array}$ & $\begin{array}{c}\text { Persentase } \\
\text { bulir isi per } \\
\text { malai (\%) }\end{array}$ & $\begin{array}{l}\text { Indeks } \\
\text { panen }\end{array}$ \\
\hline \multicolumn{7}{|c|}{ Tingkat Salinitas ( $\mathrm{NaCl})$} \\
\hline$<0,4 \mathrm{dS} / \mathrm{m}$ & $8,17 \mathrm{a}$ & 23,99 a & $\begin{array}{l}130,26 \\
a\end{array}$ & 71,28 a & $54,54 \mathrm{a}$ & 0,349 a \\
\hline $4 \mathrm{dS} / \mathrm{m}$ & $8,08 \mathrm{a}$ & 22,28 b & $\begin{array}{l}112,62 \\
a b \\
a 7,78\end{array}$ & 68,33 a & $60,61 \mathrm{a}$ & $\begin{array}{l}0,313 \\
a b\end{array}$ \\
\hline $8 \mathrm{dS} / \mathrm{m}$ & $7,33 \mathrm{a}$ & 21,42 b & $\mathrm{b}$ & 59,19 a & $62,16 \mathrm{a}$ & $0,274 \mathrm{~b}$ \\
\hline \multicolumn{7}{|c|}{ Konsentrasi Silika $\left(\mathrm{SiO}_{2}\right)$} \\
\hline $0 \mathrm{mM}$ & $7,67 p$ & $22,85 p$ & $116,09 p$ & $68,87 p$ & $59,38 p$ & $0,333 p$ \\
\hline $1 \mathrm{mM}$ & $7,78 p$ & $21,99 p$ & $104,29 p$ & $60,02 p$ & $58,72 p$ & $0,294 p$ \\
\hline $2 \mathrm{mM}$ & $7,89 p$ & $23,04 p$ & $117,55 p$ & $64,16 p$ & $56,64 p$ & $0,295 p$ \\
\hline $3 \mathrm{mM}$ & $8,11 p$ & $22,37 p$ & $116,28 p$ & $72,03 p$ & $61,67 p$ & $0,326 p$ \\
\hline Interaksi & $(-)$ & $(-)$ & $(-)$ & $(-)$ & $(-)$ & $(-)$ \\
\hline $\begin{array}{l}\text { Koefisien } \\
\text { Keragaman (\%) }\end{array}$ & 26,52 & 6,29 & 23,34 & 29,85 & 19,88 & 17,93 \\
\hline
\end{tabular}

Keterangan: (-) menunjukkan tidak ada interaksi; angka rerata yang diikuti huruf yang sama pada kolom yang sama menunjukkan tidak adanya beda nyata pada uji Duncan's Multiple Range Test pada taraf $5 \%$.

Berdasarkan Tabel 3. menunjukkan bahwa tidak ada interaksi antara konsentrasi silika dengan tingkat salinitas terhadap jumlah malai, panjang malai, jumlah bulir total per malai, jumlah bulir isi per malai, persentase bulir isi per malai, dan indeks panen padi. Perlakuan salinitas $8 \mathrm{dS} / \mathrm{m}$ berpengaruh menurunkan secara beda nyata pada panjang malai, jumlah bulir total per malai, dan indeks panen tanaman padi.Hal ini terjadi karena jumlah ion garam yang berlebihan yang masuk ke tanaman melalui aliran transpirasi menyebabkan toksisitas ion dalam sel tanaman (Djanaguiraman et al., 2006 cit. Kronzucker dan Britto, 2010). Ion garam tersebut terakumulasi di tajuk dan akan mencapai konsentrasi yang toksik seiring waktu. Toksisitas ion garam berpengaruh dalam menurunkan fungsi fisiologis dan metabolisme tanaman seperti metabolisme lemak, pembelahan sel, ketidakseimbangan hormon, dan penurunan aktivitas beberapa enzim seperti esterase, isocytric dehydrogenase, dan katalase (Swapna, 2003; Hasegawa et al., 2010; Xu et al., 2012). Penurunan kemampuan tanaman dalam pembelahan sel memungkinkan terjadinya penurunan panjang malai yang terbentuk. Menurut Rad et al. (2012) akumulasi $\mathrm{Na}^{+}$yang berlebihan pada bunga mengakibatkan terhambatnya aktivitas enzim karbohidrat sintetase dalam bulir padi dan berefek pada penurunan gabah bernas 
Afiffah Ikhsanti et. al., / Vegetalika. 2018. 7(4): 1-11

yang terbentuk. Penurunan kemampuan tanaman dalam memproduksi bulir padi menyebabkan nilai ekonomis tanaman padi menjadi semakin menurun. Akibatnya indeks panen yang merupakan perbandingan bobot gabah kering isi dengan bobot kering tanaman total pun semakin menurun pula. Perlakuan penambahan silika tidak berpengaruh secara beda nyata pada jumlah malai, panjang malai, jumlah bulir total per malai, jumlah bulir isi per malai, persentase bulir isi per malai, maupun indeks panen tanaman padi.

Tabel 4. Bobot 100 butir tanaman padi pada pengaruh tingkat salinitas dan konsentrasi silika yang berbeda

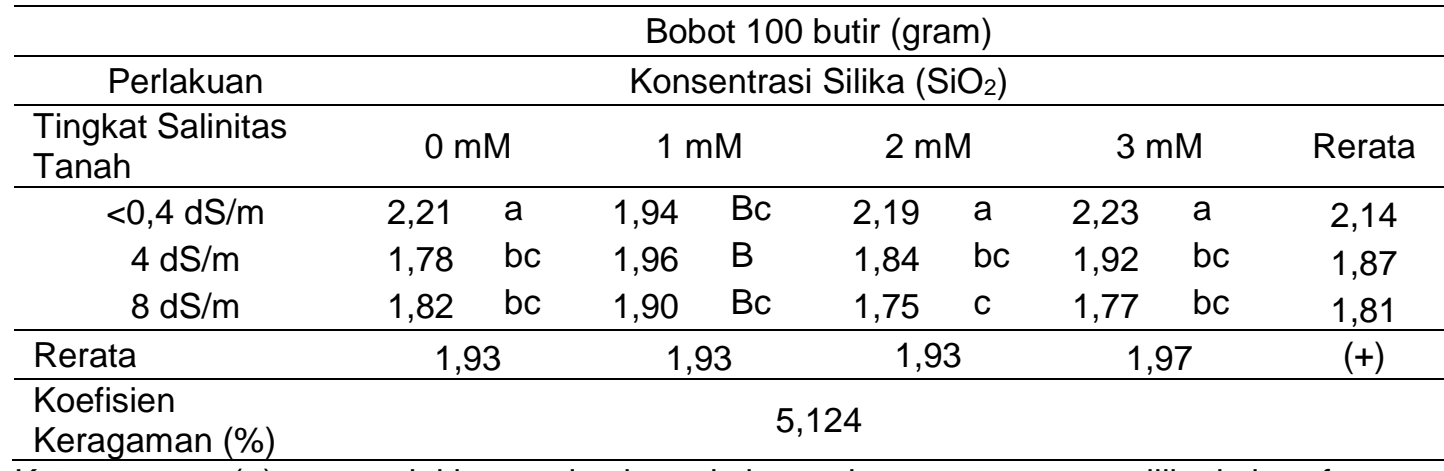

Keterangan: (+) menunjukkan ada interaksi; angka rerata yang diikuti huruf yang sama menunjukkan tidak adanya beda nyata pada uji Duncan's Multiple Range Test pada taraf $5 \%$.

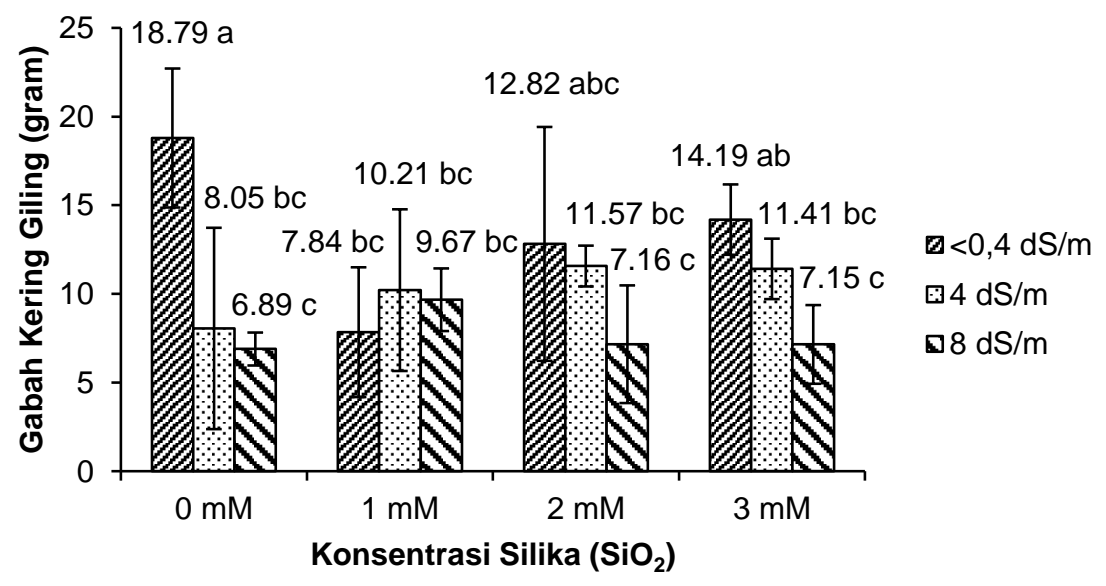

Gambar 1. Bobot gabah kering giling per rumpun tanaman padi pada pengaruh tingkat salinitas dan konsentrasi silika yang berbeda

Keterangan: Data yang ditampilkan berupa rerata \pm simpangan baku; Angka yang diikuti dengan huruf yang berbeda menunjukkan adanya beda nyata antar perlakuan tingkat salinitas berdasarkan uji Duncan's Multiple Range Test pada taraf $5 \%$. 
Afiffah Ikhsanti et. al., / Vegetalika. 2018. 7(4): 1-11

Berdasarkan Tabel 4. bobot 100 butir biji dipengaruhi oleh interaksi tingkat salinitas tanah dan konsentrasi pemberian silika. Dalam kondisi non-salin tanaman mempunyai bobot 100 butir biji lebih besar dibanding tanaman yang ditanam di bawah kondisi salin. Pada kondisi tersebut pemberian silika $1 \mathrm{mM}$, justru menurunkan bobot 100 butir biji, sedangkan konsentrasi lebih tinggi yaitu 2 dan $3 \mathrm{mM}$ tidak mempengaruhi ukuran biji padi. Pada kondisi yang lebih salin baik pada daya hantar listrik 4 maupun $8 \mathrm{dS} / \mathrm{m}$, pemberian silika pada semua kosentrasi mulai dari 1-3 mM, tidak mempengaruhi ukuran biji padi. Melihat kecenderungan tersebut secara umum dapat diketahui bahwa pemberian silika tidak mempengaruhi ukuran biji padi yang tercekam salinitas.

Gambar 1. menunjukkan bahwa pada saat tanaman padi tidak tercekam salinitas, pemberian silika sampai konsentrasi $3 \mathrm{mM}$ tidak meningkatkan hasil tanaman dan cenderung menurunkan meskipun tidak beda nyata, namun saat tercekam salinitas, pemberian silika menyebabkan tanaman dapat mempertahankan hasilnya. Tanpa pemberian silika tanaman padi tidak mampu bertahan terhadap cekaman salinitas, namun dengan pemberian silika 1-2 mM tanaman mampu bertahan terhadap kondisi salinitas hingga $8 \mathrm{dS} / \mathrm{m}$.

\section{KESIMPULAN}

Tanpa pemberian silika, tanaman padi tidak mampu bertahan terhadap cekaman salinitas dilihat dari penurunan gabah kering giling yang terjadi, sedangkan pada penambahan silika konsentrasi 1-2 mM menyebabkan tanaman mampu mempertahankan hasil hingga salinitas $8 \mathrm{dS} / \mathrm{m}$.

\section{DAFTAR PUSTAKA}

Ali, A., S.M.A. Basra, R. Ahmad and A. Wahid. 2009. Optimizing silicon application to improve salinity tolerance in wheat. Soil and Environment 28: 136-144.

BPS. 2013. Proyeksi Penduduk Indonesia 2010-2035. Badan Pusat Statistik, Jakarta.

BPS. 2016. Produksi Padi Tahun 2015 Naik 6,37 Persen. <https://www.bps.go.id/brs/view/id/1271>. Diakses pada tanggal 15 Oktober 2016. 
Das, S., P. Krishnan, N. Monalisa, B. Ramakrishnan. 2014. High temperature stress effects on pollens of rice (Oryza sativa L.) genotypes. Environmental and Experimental Botany 101: 36-46.

Grant, C.J. 1965. Soil characteristics associated with the wet cultivation of rice. In "The mineral nutrition of the rice plant" (International Rice Research Institute, Ed.) Johns Hopkins Press, Baltimore, MD.

Krishnan, P., B. Ramakrishnan, K. R. Reddy \& V. R. Reddy. 2011. High- temperature effects on rice growth, yield, and grain quality. In: Donald L. Sparks. Advances in Agronomy. Academic Press. Burlington. 1-121.

Kronzucker, H.J and D.T. Britto. 2010. Sodium transport in plants: a critical review. New Phytologist 189: 54-81.

Liang, Y., J. Si, and V. Roemheld. 2005. Silicon uptake and transport is an active process in Cucumis sativus. New Phytologist 167: 797-804.

Ma, J.F. 2004. Role of silicon in enhancing the resitance of plants to biotic and abiotic stresses. Soil Science and Plant Nutrition50:11-18.

Pitman MG 1984: Transport across the root and shoot/root interactions. In Salinity Tolerance in Plants, Strategies for Crop Improvement. Ed. RC Staples and GH Toenniessen, John Wiley and Sons, Toronto.

Rad, H.E., F. Aref, and M. Rezaei. 2012. Response of rice to different salinity levels during different growth stages. Research Journal of Applied Sciences, Engineering and Technology 4 (17): 3040-3047.

Rathnayake, W.M.U.K., R.P. De Silva, N.D.K. Dayawansa. 2016. Assessment of the suitability of temperature and relative humidity for rice cultivation in rainfed lowland paddy fields in Kurunegala District. Tropical Agricultural Research 27: 370-388.

Romero-Aranda, M.R., O. Jurado and J. Cuartero. 2006. Silicon alleviates the deleterious salt effect on tomato plant growth by improving plant water status. Journal of Plant Physiology163: 847-855.

Suwarno. 1985. Pewarisan dan Fisiologi Sifat Toleran terhadap Salinitas pada Tanaman Padi. Disertasi. Program Pasca Sarjana, Institut Pertanian Bogor, Bogor.

Warintek. 2008. Budidaya Pertanian Padi Oryza sativa. $<$ http://warintek.bantulkab.go.id/web.php?mod=basisdata\&kat=1\&sub=2\&file=60>. Diakses pada 1 Februari 2018.

Xu, R., J. Wang, C. Li, P. Johnson, C. Lu, and M. Zhou. 2012. A single locus is responsible for salinity tolerance in a Chinese landrace barley (Hordeum vulgare L.) 
Afiffah Ikhsanti et. al., / Vegetalika. 2018. 7(4): 1-11

Yeo, A.R., S.A. Flowers, G. Rao, K. Welfare, N. Senanayake, and T.J. Flowers. 1999. Silicon reduce sodium uptake in rice (Oryza sativa L.) in saline condition and this accounted for by reduction in the transpirational bypass flow. Plant Cell and Environment 22: 559-565.

Zalensky, G.L. 1999. Rice on saline soils of Russia. Cahiers Options Mediterraneennees: 109-113. 